University of Nebraska - Lincoln

DigitalCommons@University of Nebraska - Lincoln

\title{
Effects of transmission gear selection on tractor performance and fuel costs during deep tillage operations
}

\author{
C.M. Kichler \\ USDA National Soil Dynamics Laboratory, corey.kichler@ars.usda.gov \\ J.P. Fulton \\ Auburn University, fultojp@auburn.edu \\ R.L. Raper \\ USDA Dale Bumpers Small Farms Research Center, randy.raper@ars.usda.gov \\ T.P. McDonald \\ Auburn University, mcdontp@auburn.edu
}

W.C. Zech

Auburn University, zechwes@auburn.edu

Follow this and additional works at: https://digitalcommons.unl.edu/usdaarsfacpub

Part of the Agricultural Science Commons

Kichler, C.M.; Fulton, J.P.; Raper, R.L.; McDonald, T.P.; and Zech, W.C., "Effects of transmission gear selection on tractor performance and fuel costs during deep tillage operations" (2011). Publications from USDA-ARS / UNL Faculty. 861.

https://digitalcommons.unl.edu/usdaarsfacpub/861

This Article is brought to you for free and open access by the U.S. Department of Agriculture: Agricultural Research Service, Lincoln, Nebraska at DigitalCommons@University of Nebraska - Lincoln. It has been accepted for inclusion in Publications from USDA-ARS / UNL Faculty by an authorized administrator of DigitalCommons@University of Nebraska - Lincoln. 


\title{
Effects of transmission gear selection on tractor performance and fuel costs during deep tillage operations ${ }^{\text {光 }}$
}

\author{
C.M. Kichler ${ }^{\text {a }}$, J.P. Fulton ${ }^{\text {b,* }}$, R.L. Raper ${ }^{\text {c }}$, T.P. McDonald ${ }^{\text {b }}$, W.C. Zech $^{\text {d }}$ \\ a USDA National Soil Dynamics Laboratory, 411 South Donahue Dr., Auburn, AL 36832, USA \\ ${ }^{\mathrm{b}}$ Biosystems Engineering Department, Auburn University, 200 Tom E. Corley Building, Auburn, AL 36849, USA \\ ' USDA Dale Bumpers Small Farms Research Center, 6883 So. St. Hwy 23, Booneville, AR 72927, USA \\ d Civil Engineering Department, Auburn University, 283 Harbert Engineering Center, Auburn, AL 36849, USA
}

\section{A R T I C L E I N F O}

\section{Article history:}

Received 24 November 2010

Received in revised form 4 March 2011

Accepted 7 March 2011

\section{Keywords:}

Data acquisition

Power

Torque

Tractor performance

Subsoiler

Site-specific

\begin{abstract}
A B S T R A C T
Deep tillage operations required to alleviate soil compaction common in the Southeastern US remain energy intensive and expensive. Equipment performance and in-field efficiency are two variables that can be improved to minimize fuel consumption and ultimately reduce input costs for crop production. The objective of this study was to investigate the effects of transmission gear selection on fuel costs, draft, and other equipment performance variables using two deep tillage implements. Three different transmission gears were selected which represented slow, normal, and fast operating speeds for two typical in-row, integral subsoilers (KMC generation I rip-strip and Bigham Brothers Paratill ${ }^{\mathrm{TM}}$ ). Tractor fuel consumption, slip, axle torque, and engine speed were measured in real-time along with transverse and vertical draft forces. Results indicated a $105 \%$ increase in fuel consumption rate, a $28 \%$ increase in implement draft, and a $255 \%$ increase in power between the slow and fast speed for the Paratill ${ }^{\mathrm{TM}}$. The KMC showed a $115 \%$ increase in fuel consumption rate, a $37 \%$ increase in implement draft, and a $283 \%$ increase in power between the slow and fast speeds. Good comparisons were found between measured and estimated, using published equations, for fuel consumption $(-5.3 \%$ to $4.9 \%)$ and draft $(-3.6 \%$ to $17.7 \%$ ). For the Paratill ${ }^{\mathrm{TM}}$, the normal speed produced the lowest fuel cost $(\$ 5.10 / \mathrm{ha})$ but operating at this speed reduced productivity rate from $4.55 \mathrm{ha} / \mathrm{h}$ at the fast speed down to $3.23 \mathrm{ha} / \mathrm{h}$. Conversely, the KMC fast speed provided the lowest fuel cost $(\$ 5.35 / \mathrm{ha})$ and highest productivity rate $(4.35 \mathrm{ha} / \mathrm{h})$ for this implement. In general, the Paratill ${ }^{\mathrm{TM}}$ provided the highest productivity and lowest fuel cost when operated at the typical speeds in the Southeastern US (around the normal to fast) mostly likely due to the lower required draft. In summary, the minimum fuel usage for each implement occurred at a different ground speed however, productivity was maximized at the fast speed with data reported useful to practitioners managing these style tillage implements.
\end{abstract}

Published by Elsevier B.V.

\section{Introduction}

Soil compaction layers found in the Southeastern United States require farmers to regularly perform deep tillage operations prior to spring planting in order to control this issue to maximize crop

\footnotetext{
Mention of trade names and commercial products is for informational purposes and does not imply endorsement by Auburn University or the Alabama Agricultural Experiment Station.

Abbreviations: FC, fuel consumption; MC, soil moisture content; db, dry basis; DBD, soil dry bulk density; CI, cone index; SD, standard deviation; GS, ground speed; Vert, vertical force; RMSE, root mean square error; LSD, least significant difference; LSR, least squares regression.

* Corresponding author. Tel.: +1 334844 3541; fax: +1 3348443530 .

E-mail addresses: corey.kichler@ars.usda.gov (C.M. Kichler), fultojp@auburn. edu (J.P. Fulton), randy.raper@ars.usda.gov (R.L. Raper), mcdontp@auburn.edu (T.P. McDonald), zechwes@auburn.edu (W.C. Zech).
}

yields. These compacted layers tend to occur naturally within certain soil types but are also a result of the heavy equipment that are used to manage crops. Many researchers have studied the effects of deep tillage on these soils and have often reported yield increases for crops (Box and Langdale, 1984; Busscher et al., 1988; Chancy and Kamprath, 1982; Reeves and Touchton, 1986; Sene et al., 1985; Wagger et al., 1992). It has been reported that subsoiling increases the utilization of subsoil moisture in soils with root limiting compaction layers (Kamprath et al., 1979). Deep tillage or subsoiling operations are energy intensive and can be costly to agricultural producers especially if performed on a yearly basis. In the Southeast US, deep tillage typically occurs at a depth of $30.5-38.1 \mathrm{~cm}$. Due to energy requirements of deep tillage, tractor fuel consumption is higher when compared to other tillage operations that are focused more on surface disruption. With escalated fuel costs in 2007-2008 and unpredictability of future 
prices, producers are searching for ways to improve machinery fuel economy in order to minimize input costs and remain competitive in today's global agricultural economy.

Residual organic matter (OM) from previous crops is essential to retaining soil moisture, reducing soil erosion, and suppressing weed growth for conservation systems (Baldwin, 2006). An increase in soil OM can also decrease soil compactibility (Larson and Allmaras, 1971; Howard et al., 1981; and Free et al., 1947). The existence of $\mathrm{OM}$ within soil horizons helps reduce both bulk density and penetration resistance, thus increasing the ability of soil to retain and transport water (Ohu et al., 1994). Most farmers use crop residue left after harvest to take advantage of the benefits of increase in soil OM content of their cropland. Conservation tillage systems are designed to minimize aboveground soil disruption while still alleviating belowground soil compaction layers. Raper (2005) investigated straight and bentleg subsoiler shank designs and their effects on above and belowground soil disruption and draft forces. Results indicated that bentleg shanks produced lower draft forces compared to the straight shanks. However, the bentleg shanks generated increased lateral force compared to the straight shank designs.

Raper and Bergtold (2007) recommended subsoiling when soil has adequate moisture so that soil surface disruption and energy requirements can be minimized. They reported a $19 \%$ fuel savings and a $28 \%$ draft reduction by avoiding tillage in dry conditions. One suggested method of reducing fuel consumption during field operations is the "gear up, throttle down" operating technique (Grisso and Pitman, 2001). The idea was to operate tractors, when pulling lighter loads, in a higher gear but decrease engine speed while maintaining the same ground speed resulting in reduced fuel usage. It should be noted that the engine operating map does highly influence the relationship between ground speed, engine RPM, gear selection and fuel consumption.

Schrock et al. (1982) developed a microprocessor based gear selection aid for an agricultural tractor. Developed algorithms used variables including engine and transmission speed along with fuel injector rack position information to predict and display a recommended transmission gear. The algorithm optimized tractor performance based on the field operation being performed. Gear recommendations were based on the "gear up, throttle down" operating technique with results indicating a $19.8 \%$ savings in fuel consumption using their system compared to the operator's selected gear and throttle selection. Turner (1993) devised a data acquisition system to determine an agricultural machine's tractive performance in the field. His system measured vehicle ground speed, traction surface speed, and draft force in order to estimate tractive efficiency (TE) to maximize tractor performance. Tractive performance describes the ability of the tractor to generate pulling power which considers the interaction between the running gear (e.g., wheels or tracks) and soil such as slip and motion resistance. Five dimensionless characterize tractive performance: travel reduction ratio, net traction ratio, tractive efficiency, gross traction ratio and motion resistance ratio (Zoz and Grisso, 2003). As an example, Bashford et al. (1999) evaluated tractive performance for tractors by comparing dynamic traction ratio, tractive efficiency and slip.

Jenane et al. (1996) investigated the relationship between tractive performance and specific fuel consumption of agricultural tractors over a range of field conditions. They indicated that the main variable that restricts higher drawbar pulling efficiency was excessive wheel slippage. Further, they also reported that soil type, soil condition, tractor configuration, and hitch type affect slip. Field testing concluded that fuel consumption was optimal when the tractor operated near maximum tractive performance. Increased fuel efficiency was found to be within a slip range of $10-30 \%$.

The American Society of Agricultural and Biological Engineers (ASABE) has published draft estimation equation (Eq. (1)) in
Table 1

Summary of measured soil data by implement and speed treatments.

\begin{tabular}{llllll}
\hline Implement & Treatment & $\begin{array}{l}\text { MC } \\
(\% \mathrm{db})^{\mathrm{a}}\end{array}$ & $\begin{array}{l}\text { DBD } \\
\left(\mathrm{g} / \mathrm{cm}^{3}\right)\end{array}$ & $\begin{array}{l}\text { CI } \\
(\mathrm{MPa})\end{array}$ & $\begin{array}{l}\text { Tillage } \\
\text { depth }(\mathrm{cm})\end{array}$ \\
\hline Paratill $^{\mathrm{TM}}$ & Slow & $15.5^{\mathrm{ab}}$ & $1.41^{\mathrm{c}}$ & $2.46^{\mathrm{f}}$ & $29.8^{\mathrm{ab}}$ \\
Paratill $^{\mathrm{TM}}$ & Normal & $15.7^{\mathrm{a}}$ & $1.47^{\mathrm{b}}$ & $3.07^{\mathrm{cd}}$ & $28.4^{\mathrm{bc}}$ \\
Paratill $^{\mathrm{TM}}$ & Fast & $14.2^{\mathrm{b}}$ & $1.50^{\mathrm{a}}$ & $3.16^{\mathrm{bc}}$ & $31.3^{\mathrm{a}}$ \\
KMC & Slow & $15.6^{\mathrm{ab}}$ & $1.40^{\mathrm{c}}$ & $3.47^{\mathrm{a}}$ & $26.5^{\mathrm{c}}$ \\
KMC & Normal & $15.6^{\mathrm{ab}}$ & $1.46^{\mathrm{b}}$ & $2.87^{\mathrm{d}}$ & $26.2^{\mathrm{c}}$ \\
KMC & Fast & $12.6^{\mathrm{c}}$ & $1.46^{\mathrm{b}}$ & $3.44^{\mathrm{ab}}$ & $26.5^{\mathrm{c}}$ \\
& LSD & 1.4 & 0.02 & 0.28 & 2.8
\end{tabular}

MC: moisture content; db: dry basis; DBD: dry bulk density; $\mathrm{CI}$ : cone index; SD standard deviation; LSD: least significant difference.

a Means with similar letters in columns are not statistically different $(P>0.05)$.

Standard D497.6 (ASABE Standards, 2009a) for various agricultural implements. This formula uses a variety of field and machine coefficients to estimate implement draft.

$D=F_{i}\left[A+(B \times S)+\left(C \times S^{2}\right)\right] W T$

where $D=$ implement draft $(\mathrm{N}), F=$ dimensionless soil texture adjustment (table), $i=1$ for fine, 2 for medium, 3 for coarse textured soils, $A, B$, and $C=$ machine specific coefficient (Table 1 ), $S=$ field speed $(\mathrm{km} / \mathrm{h}), W=$ machine width, $(\mathrm{m})$ or number of tools (table), and $T=$ tillage depth $(\mathrm{cm})$. Parameters are listed for two types of subsoilers, narrow point and $30-\mathrm{cm}$ winged point, with estimates potentially varying within $50 \%$. More recently, manufacturers have developed different subsoiler shanks such as the "bentleg" design which may require updates to the ASABE standard to better reflect actual implement draft for these type shanks.

Measured draft and fuel consumption in this study were compared to published equations to estimate these variables. Raper et al. (2005) developed an equation (Eq. (2)) to estimate fuel consumption during deep tillage for the John Deere 8300 tractor used in this study. Power-take-off data was converted to drawbar power using data available from the Nebraska Tractor Test.

$\mathrm{FC}=0.31 \mathrm{DP}+9.14$

where $\mathrm{FC}=$ fuel consumption $(\mathrm{L} / \mathrm{h})$ and $\mathrm{DP}=$ drawbar power $(\mathrm{kW})$.

The goal of this research is to develop equipment management strategies to improve in-field operations and reduced energy usage. The objectives of this study were to: (1) compare and contrast the energy requirements of two common deep tillage implements used in the Southeast US operating at different ground speeds, and (2) compute productivity and fuel costs for operating these two implements and compare measured results to estimated variables using published equations.

\section{Materials and methods}

A 0.5-ha field located at the E.V. Smith Research Center in Shorter, AL, USA was the site selected for this study. A Luverne soil series existed at this site with a fine,mixed, semiative, thermic Typic Hapludults taxonomy. A mechanical front wheel drive (MFWD) John Deere 8300 agricultural tractor (Fig. 1) with a full powershift transmission and rear axle differential lock equipped with a Real-Time Kinematic (RTK) Trimble AutoPilot guidance system was used during all tests. The auto-guidance system helped maintain a straight path over plot centers during tillage. Tires for the front were radial $16.9 \mathrm{R} 30$ inflated at $159 \mathrm{kPa}$ with the rear being radial $18.4 \mathrm{R} 46$ at $165 \mathrm{kPa}$. The 3-point hitch was used to raise and lower the implements with the hydraulics set to control the desired tillage depth for each implement.

Two deep tillage implements were used and represented typical subsoilers used in the southeastern US to alleviate soil compaction 


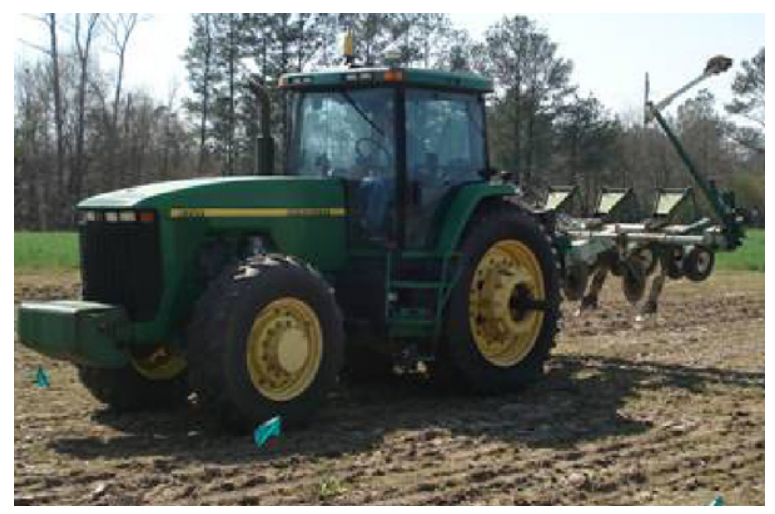

Fig. 1. John Deere 8300 MFWD with integral mounted KMC Generation I Rip-Strip unit used during this study.

while minimizing surface disruption: a KMC Generation I Rip-Strip subsoiler (Fig. 1) and a Bigham Brothers Paratill ${ }^{\mathrm{TM}}$. Both implements were three-point hitch or integral mounted and configured for six-rows (i.e., 6 shanks) having 5.5-m working widths. The KMC implement had a straight shank design with the Paratill ${ }^{\mathrm{TM}}$ a bentleg design (Fig. 2). A typical setup for on-farm use was used with appropriate loadings for a John Deere 8300 (149-kW PTO power rating; Deere and Company, Moline, IL). The power ratings for these implements were $22-30 \mathrm{~kW}$ per shank for the Paratill ${ }^{\mathrm{TM}}$ (Bigham Brothers, 2009) and 19-22 kW per shank for the KMC Generation I Rip-Strip subsoiler (Sumner, 2007).

The experimental design for this study was a $2 \times 3$ factorial split plot design with tillage implements as main plots (Paratill and KMC) and speeds (slow, normal, and fast; horizontal direction) as sub-main plots. In the vertical direction were four replications. Plots measured $30.5-\mathrm{m}$ long by $5.5-\mathrm{m}$ wide. Each pass consisted of 3 plots with a 15-m transition area between each plot. Gear changes occurred within this transition area without stopping or raising the implement out of the ground allowing the equipment to reach steady-state operating conditions before entering the next plot.

Preliminary testing determined how the tractor responded to on-the-go gear changes under load while being cautious of engine overloading when operating in higher gears. The gears selected based on the preliminary testing were 2 nd (approx. $3.0 \mathrm{~km} / \mathrm{h}$ ) for the slow treatment, 5th (approx. $5.8 \mathrm{~km} / \mathrm{h}$ ) for normal, and 8th (approx. $8.3 \mathrm{~km} / \mathrm{h}$ ) for fast. The targeted nominal tillage depth was $30 \mathrm{~cm}$ and was preset prior to initiating this study. Actual depth of tillage was evaluated by extracting the soil disrupted by a shank and measuring the distance from the soil surface to the bottom of the disrupted area. This depth was measured at one location within each plot. Once the tractor was aligned with the plot, the MFWD and axle differential lock were engaged with the tractor engine set to full throttle. The implement was then lowered to the preset depth initiating a pass.

Equipment performance data collected during testing included: fuel consumption, axle torque, wheel speed, ground speed, engine speed, and draft. A Corrsys Datron (Welzer, Germany) fuel sensor (model number CDS-DFL3) was utilized to measure real-time fuel consumption of the JD 8300 diesel engine. This sensor has an integrated reservoir to measure volume of fuel used and accounts for fuel temperature variations along with the amount of bypassed fuel back to the tank. Axle torque was measured using a Binsfeld Engineering (Maple City, MI, USA) TorqueTrak 9000 transducer mounted on the tractor's right rear axle. This sensor uses a 4-arm Wheatstone bridge strain gage and required a calibration procedure to eliminate any pre-strain once the sensor was adhered to the axle. Wheel speed was measured using the existing transmission speed sensor with ground speed determined using a DICKEY-john ${ }^{\mathbb{R}}$ ground speed radar. An existing Hall Effect sensor on the tractor provided engine speed. Draft data was collected using a three-dimensional (transverse, vertical, and lateral directions) draft dynamometer fabricated by the USDA-Agricultural Research Service National Soil Dynamics Laboratory in Auburn, AL, USA. Only the transverse and vertical draft measurements were used in this study. For the vertical force, a negative value indicated an upward force on the implement while positive values represented the implement being pulled downward. The draft data was collected using an independent acquisition system that was not based on the tractor data collection system. Data were recorded to text files containing time stamps from both data acquisition systems allowing both data sets to be corresponding matched and then merged for analyses. The sampling frequency for all data collection was set at $1 \mathrm{~Hz}$. The traversal draft was converted to drawbar power using the following equation (ASABE Standards, 2009b):

$P=\frac{D \times S}{3}$

where $P=$ drawbar power $(\mathrm{kW}), D=$ implement draft $(\mathrm{kN})$, and $s=$ speed $(\mathrm{km} / \mathrm{h})$.

Soil data collected included cone penetrometer (cone index, $\mathrm{CI}$ ), moisture content (MC), and dry bulk density (BD). Three $\mathrm{CI}$ and soil cores were collected within each plot. A Multiple-Probe Soil Cone Penetrometer (MPSCP) fabricated by the USDA- Agricultural Research Service National Soil Dynamics Laboratory in Auburn, AL, USA was used to collect penetrometer data for each plot prior to tillage (Raper et al., 1999). Cone index (CI) readings were measured in 5.08-cm increments with final data averaged over the depth of tillage for analysis. Undisturbed soil core samples for bulk density and moisture content dry basis ( $\mathrm{db}$ ) were collected using a core sampling tube attachment mounted to the MPSCP frame. The soil

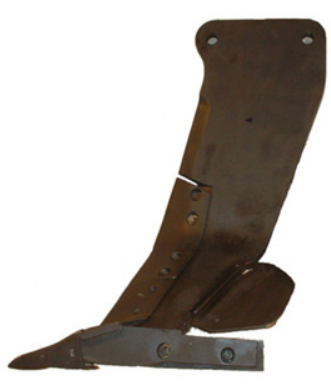

(a)

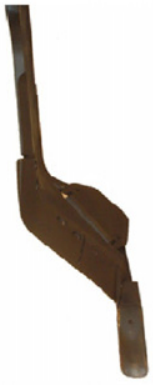

(b)

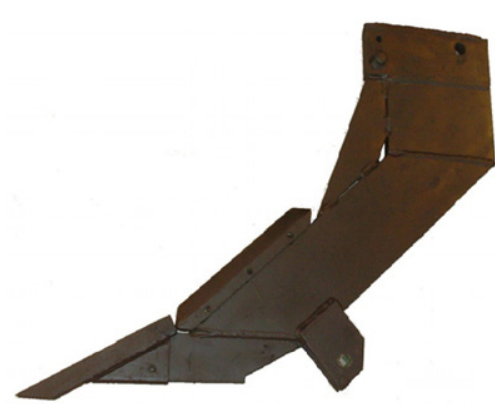

(c)

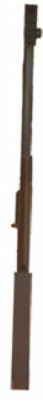

(d)

Fig. 2. Illustration of the Paratill ${ }^{\mathrm{TM}}$ shank (a) side, (b) front views along with the KMC shank (c) side and (d) front views. Images courtesy of Raper et al., 2005. 
core sampling tube contained an inner cylinder which allowed extracted cores to be split into 5 - $\mathrm{cm}$ increments. The individual 5$\mathrm{cm}$ increments were placed in tin cans and labeled accordingly. The wet weight of each sample was measured with the samples oven dried at $105{ }^{\circ} \mathrm{C}$ for $72 \mathrm{~h}$. The dry samples were then weighed again to calculate MC and BD.

Field productivity rate (Eq. (4)) along with fuel costs (Eq. (5)) were estimated for each of these implements operated at the three different ground speeds. Productivity rate for this study referred to the area tilled per hour using the measured ground speed and fixed implement working width. Fuel cost was expressed as the cost of fuel consumed per hectare and computed using Eq. (5) assuming a cost of US\$ 0.62/L for this analysis.

$\mathrm{PR}=\frac{\mathrm{GS} \times \mathrm{WW}}{10}$

where $P R=$ productivity rate $(\mathrm{ha} / \mathrm{h}), \mathrm{GS}=$ ground speed $(\mathrm{km} / \mathrm{h})$, and $\mathrm{WW}=$ working width $(\mathrm{m})$, and

Fuel cost $=\mathrm{FC} \times \frac{1}{\mathrm{PR}} \times \mathrm{FP}$

where fuel cost $(\$ / h a), F C=$ fuel consumption $(L / h), P R=$ productivity rate $(\mathrm{ha} / \mathrm{h})$, and $\mathrm{FP}=$ fuel price $(\$ / \mathrm{L})$.

Traverse draft measured with the dynamometer was compared to the estimated draft calculated using Eq. (1) (ASABE Standards, 2009a). The implement used for the estimated draft was a subsoiler, narrow point. The machine parameters selected for use in Eq. (1) were $A=226, B=0$, and $C=1.8$ while the soil parameter selected was $F_{2}(=0.70$; medium textured soil). Since both implements were setup similarly, $W=6$ (tools or points) and $T=33.02 \mathrm{~cm}$. The measured ground speed was used in these calculations with the percent difference of the estimated draft from the actual computed for comparison.

An analysis of variance (ANOVA) using SAS 9.1 (SAS Institute Inc., Cary, NC, USA) was conducted to test for differences between (1) treatments (speed and implement) for the measured tractor performance and soil variables and (2) measured and estimated productivity rate and fuel costs. A least squares regression (LSR) was applied to evaluate linear relationships between fuel consumption and implement draft along with tractor power and fuel consumption for each implement. SAS was also used to determine if LSR slopes and $y$-intercepts were statistically different between implements and compute the root mean square error (RMSE) for all regression fits. The estimated and actual fuel consumption and draft data for the John Deere 8300 tractor was analyzed using the same LSR procedure within SAS. All statistical tests were performed at the $95 \%$ confidence interval.

\section{Results and discussion}

Soil moisture content (MC) ranged from $12.6 \%$ to $15.7 \%$ dry basis for the study site (Table 1). Statistical differences were found in the fast treatment plots with the slow and normal plots being statistically similar. The MC for the KMC Fast treatment was lower compared to all other treatments at $12.6 \%$ which coincided with the higher cone index (CI) measurements. Some statistical differences in dry bulk density (DBD) and Cone Index (CI) existed between treatments but were considered only small differences for this site. The actual depth of tillage (Tillage Depth) was significantly different between implements. The tillage depth for the KMC was consistent over the three speed treatments averaging around $26.4 \mathrm{~cm}$. Conversely, the Paratill tillage depth resulted in statistical differences between the slow and normal treatments versus the fast. The cause of this variability in tillage depth will be discussed later. However, adjustment of the 3-point hitch depth setting could have helped maintain a similar depth setting between implements but would have required extensive setup time to properly determine the correct settings. We conducted preliminary testing in an attempt determine the correct 3-point hitch depth setting but the different vertical forces, unknown at the time and discussed later, generated these measured differences. One must remember that the 3-point hitch system on this tractor provides lift capacity and not down force. Overall, the soil properties were considered consistent between plots.

Table 2 presents the summarized performance data. There were some differences in the resulting ground speeds between the Paratill and KMC implements. The ground speeds for the Paratill tended to be higher than the KMC. The lower ground speed for the KMC could be contributed to the higher slip and $\mathrm{CI}$ values along with lower soil MC (Tables 1 and 2). While slight differences were observed in engine speed, the engine speed ranged between $2239 \mathrm{rpm}$ and $2275 \mathrm{rpm}$ and were statistically the same for each speed between implements. Slip was near 0\% for the Paratill over all three speeds but between $1 \%$ (slow) and 4\% (fast) for the KMC. Again, the higher slip values for the KMC could be partially due to the higher $\mathrm{CI}$ in those plots along with lower soil MC. These slip values were considered low for all treatments and could be contributed to optimal soil conditions for tillage along with the tractor having sufficient power (rated at $149 \mathrm{~kW}$ ) and traction to pull these implements.

Performance data was affected by the speed treatments (Table 2 ). The fuel consumption (FC) for the Paratill ${ }^{\mathrm{TM}}$ was statistically similar to that of the KMC for each of the equivalent speeds. Increases in FC of $40 \%$ (slow vs. normal), $47 \%$ (normal vs. fast) and $105 \%$ (slow vs. fast) were observed between treatments for the Paratill $^{\mathrm{TM}}$. The KMC produced a $66 \%$ increase (slow vs. normal), $30 \%$ increase (normal vs. fast), and $115 \%$ increase (slow vs. fast) in FC. Overall, FC illustrated an expected increasing trend as speed increased for both implements.

The Paratill ${ }^{\mathrm{TM}}$ results indicated no statistical difference in draft between the slow and normal speeds, however, a slight decrease in draft was observed at the normal speed. A significant increase in draft for the Paratill ${ }^{\mathrm{TM}}$ of approximately $28 \%$ and $33 \%$ existed for the fast speed over the slow and normal speeds, respectively. Draft steadily increased for the KMC as speed increased. A significant increase in draft of $25 \%$ existed between the slow and normal

Table 2

Summary of mean performance data for each implement by speed treatment.

\begin{tabular}{|c|c|c|c|c|c|c|c|c|}
\hline Implement & $\mathrm{GS}(\mathrm{km} / \mathrm{h})^{\mathrm{a}}$ & Slip \%) & Engine (RPM) & $\mathrm{FC}(\mathrm{L} / \mathrm{h})$ & Torque $(\mathrm{N} \mathrm{m})$ & Power (kW) & Draft $(\mathrm{N})$ & Vert $(\mathrm{N})$ \\
\hline Paratill $^{\mathrm{TM}}$ & $3.0^{\mathrm{e}}$ & $0.1^{\mathrm{c}}$ & $2,275^{\mathrm{ab}}$ & $18.9^{c}$ & $13,631^{b}$ & $28.2^{\mathrm{d}}$ & $34,130^{\mathrm{b}}$ & $4,414^{\mathrm{b}}$ \\
\hline Paratill $^{\mathrm{TM}}$ & $5.8^{\mathrm{c}}$ & $0.1^{\mathrm{c}}$ & $2,264^{\mathrm{bc}}$ & $26.4^{\mathrm{b}}$ & $13,489^{b}$ & $52.9^{c}$ & $32,719^{b}$ & $4,112^{\mathrm{b}}$ \\
\hline Paratill $^{\mathrm{TM}}$ & $8.3^{\mathrm{a}}$ & $0.5^{\mathrm{bc}}$ & $2,239^{d}$ & $38.8^{\mathrm{a}}$ & $13,938^{a}$ & $100.7^{\mathrm{a}}$ & $43,633^{a}$ & $7,654^{a}$ \\
\hline KMC & $2.9^{\mathrm{e}}$ & $1.3^{\mathrm{b}}$ & $2,275^{\mathrm{a}}$ & $17.7^{\mathrm{c}}$ & $13,119^{c}$ & $26.8^{d}$ & $32,450^{\mathrm{b}}$ & $-3,087^{c}$ \\
\hline KMC & $5.6^{\mathrm{d}}$ & $2.9^{\mathrm{a}}$ & $2,260^{c}$ & $29.3^{b}$ & $13,920^{a}$ & $65.6^{\mathrm{b}}$ & $40,581^{a}$ & $-1,654^{\mathrm{c}}$ \\
\hline KMC & $8.0^{\mathrm{b}}$ & $3.5^{\mathrm{a}}$ & $2,246^{\mathrm{d}}$ & $38.1^{\mathrm{a}}$ & $14,050^{\mathrm{a}}$ & $103.1^{\mathrm{a}}$ & $44,559^{a}$ & $-885^{c}$ \\
\hline LSD & 0.1 & 0.8 & 12 & 5.2 & 284 & 9.4 & 4963 & 2304 \\
\hline
\end{tabular}

FC: fuel consumption; GS: ground speed; Vert: vertical force; LSD: least significant difference.

a Means with similar letters in columns are not statistically different $(P>0.05)$ 
speeds for the KMC. While not significant, a $10 \%$ increase in draft for the KMC occurred between the normal and fast speeds.

Results indicated statistical differences in vertical forces and tillage depths between the Paratill ${ }^{\mathrm{TM}}$ and KMC. Tillage depths were $2-5 \mathrm{~cm}$ different between the implements, most likely due to the differences in vertical forces. The KMC generated negative vertical forces which caused the implement to be pushed upward during tillage, thus decreasing the tillage depth. Conversely, the bentleg design of the Paratill ${ }^{\mathrm{TM}}$ generated positive vertical forces thereby pulling itself into the ground yielding slightly deeper tillage depths over the KMC. The vertical forces across the speed treatments were statistically similar for the KMC but the trend was that this force decreased as speed increased. For the Paratill ${ }^{\mathrm{TM}}$, the high speed vertical force was statistically and much higher than the slow and normal speeds. While the reason for this difference is unknown, the larger vertical force caused the tillage depth to be about $2 \mathrm{~cm}$ deeper over the other two speeds. With the Paratill ${ }^{\mathrm{TM}}$ shanks being longer since "bent," this increase in tillage depth impacts implement draft loads.

In terms of axle torque, no statistical differences in axle torque existed between the normal and fast speeds for the KMC as well as the slow and normal speeds for the Paratill ${ }^{\mathrm{TM}}$. Results for the Paratill $^{\mathrm{TM}}$ did show decreases in draft and axle torque between the slow and normal speeds indicating that the implement was able to move through the soil with less effort for the normal speed compared to the slow speed. A slightly increasing trend in axle torque was noticed as speed increased for the KMC. Torque was correlated with draft and tended to increase with speed with significant differences between slow and fast speeds.

Fig. 3 illustrates the relationship between fuel consumption and draft for the Paratill ${ }^{\mathrm{TM}}$ and KMC implements. A strong linear relationship $\left(r^{2}=0.85\right.$; RMSE $\left.=4.0 \mathrm{~L} / \mathrm{h} ; P<0.001\right)$ existed for the KMC while only a moderate relationship existed for the Paratill ${ }^{\mathrm{TM}}$ $\left(r^{2}=0.59 ;\right.$ RMSE $\left.=6.1 \mathrm{~L} / \mathrm{h} ; P=0.0036\right)$. Reasons for the moderate linear relationship for the Paratill ${ }^{\mathrm{TM}}$ could be explained by the fact that the normal speed experienced a decrease in draft but an increase in fuel consumption compared to the slow speed. In Table 1 , although not significant, the Paratill ${ }^{\mathrm{TM}}$ normal speed treatment had the shallowest tillage depth and the highest moisture content for all three Paratill ${ }^{\mathrm{TM}}$ plots. No significant difference in slope $(P=0.8522)$ or $y$-intercept $(P=0.1468)$ were found between the LSR lines. Therefore, an overall linear fit was computed indicating a good linear relationship between fuel consumption and draft $\left(r^{2}=0.69 ;\right.$ RMSE $=5.2 \mathrm{~L} / \mathrm{h}$ ) for this tractor (Fig. 3).

As expected, results indicated that as ground speed increased so did the required power and thereby FC for both implements

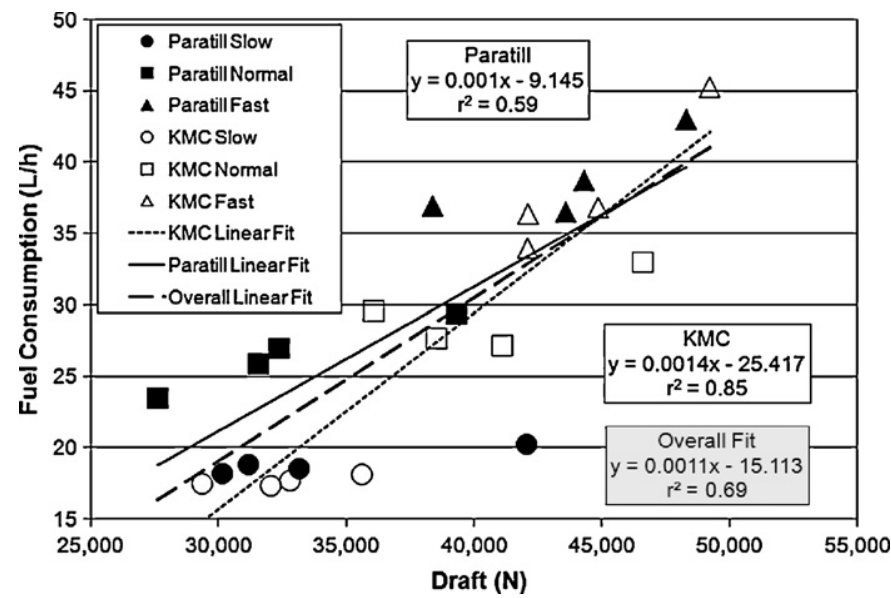

Fig. 3. Plot of fuel consumption vs. draft force with linear fit for each implement plus overall linear fit.

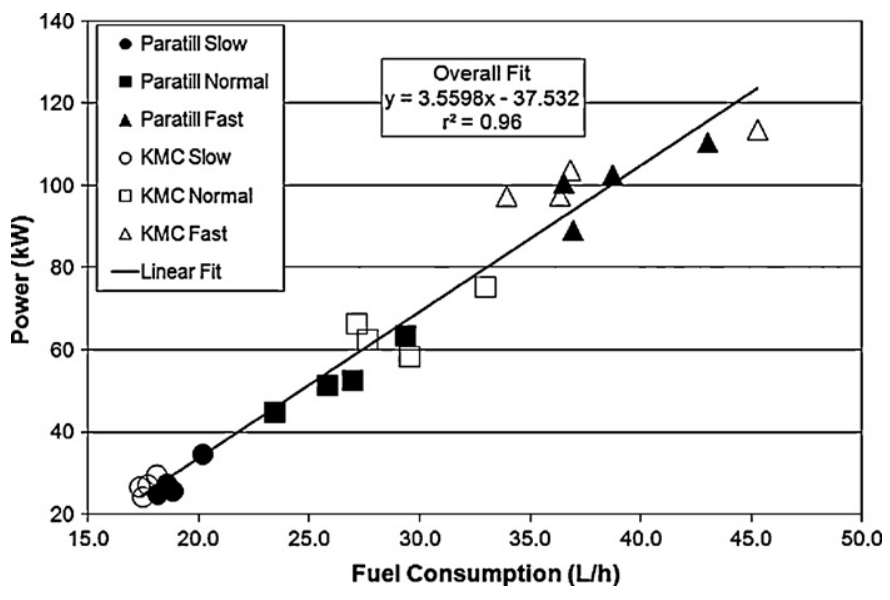

Fig. 4. Plot of power vs. fuel consumption for all treatments along with the linear fit.

(Fig. 4). A strong linear relationship existed between power and FC for the Paratill ${ }^{\mathrm{TM}}\left(r^{2}=0.98 ; \quad \mathrm{RMSE}=4.3 \mathrm{~kW}\right)$ and the KMC $\left(r^{2}=0.95 ;\right.$ RMSE $\left.=8.0 \mathrm{~kW}\right)$. However, no significant differences existed between the slopes $(P=0.6357)$ and $y$-intercepts $(P=0.3936)$ for these LSR fits so an overall LSR linear fit was computed $\left(r^{2}=0.96\right.$; RMSE $\left.=6.2 \mathrm{~kW}\right)$. The linear fit resulted in a slope of $3.56 \mathrm{~kW}$ per $\mathrm{L} / \mathrm{h}$ and illustrated that speed significantly impacted FC and required power regardless of the implement. Further, the Paratill ${ }^{\mathrm{TM}}$ produced an $89 \%$ increase in power from the slow to normal speed and a $91 \%$ power increase from the normal to fast speed. Large increases in power were noticed between the slow and fast speeds for the Paratill ${ }^{\mathrm{TM}}$ (261\%) and the KMC (281\%). At the normal speed, a statistical $25 \%$ increase in power was required for the $\mathrm{KMC}$ over the Paratill ${ }^{\mathrm{TM}}$ suggesting that the Paratill $^{\mathrm{TM}}$ was designed to operate around the normal speed.

The estimated productivity rate and fuel costs for both implements showed that operating at the fast ground speed generated the highest productivity rate for both implements (Table 3). Statistical differences existed in productivity rates except at the slow speed for both implements. The Paratill ${ }^{\mathrm{TM}}$ generated higher productivity rates at each speed with the differences between productivity rate increasing as speed increased. This result can be contributed to the lower draft forces causing slightly higher ground speed for the Paratill ${ }^{\mathrm{TM}}$ over the KMC at each speed treatment. Further, it should again be noted that the KMC plots had higher $\mathrm{CI}$ and lower soil MC which could have contributed to these differences between implements. Of note, even though the slow speed for both implements yielded lower fuel consumption rates, the lower productivity rates associated with the slow speeds resulted in increased cost per hectare at this speed compared to the normal and fast speeds. Productivity increased $177 \%$ (slow vs. fast), 97\% (slow vs. normal) and $41 \%$ (normal vs. fast) for the Paratill ${ }^{\mathrm{TM}}$. No significant differences in fuel costs were found between the

Table 3

Estimated productivity rate and fuel cost for each implement.

\begin{tabular}{llll}
\hline Implement & Treatment & $\begin{array}{l}\text { Productivity } \\
\text { rate (ha/h) }\end{array}$ & Fuel cost (US\$/ha) \\
\hline Paratill $^{\mathrm{TM}}$ & Slow & $1.64^{\mathrm{e}}$ & $7.17^{\mathrm{a}}$ \\
Paratill $^{\mathrm{TM}}$ & Normal & $3.21^{\mathrm{c}}$ & $5.10^{\mathrm{b}}$ \\
Paratill $^{\mathrm{TM}}$ & Fast & $4.55^{\mathrm{a}}$ & $5.29^{\mathrm{b}}$ \\
KMC & Slow & $1.61^{\mathrm{e}}$ & $6.78^{\mathrm{a}}$ \\
KMC & Normal & $3.11^{\mathrm{d}}$ & $5.86^{\mathrm{b}}$ \\
KMC & Fast & $4.42^{\mathrm{b}}$ & $5.35^{\mathrm{b}}$ \\
& LSD & 0.05 & 0.90
\end{tabular}

LSD: least significant difference.

${ }^{a}$ Means with similar letters in columns are not statistically different $(P>0.05)$. 
Table 4

Summarized estimates of actual fuel consumption and implement draft for each implement by speed.

\begin{tabular}{|c|c|c|c|c|c|c|c|}
\hline Implement & Speed $(\mathrm{km} / \mathrm{h})$ & Actual FC (L/h) & Est FC $(\mathrm{L} / \mathrm{h})^{\mathrm{a}}$ & Diff (\%) & Actual Draft (N) & Est. Draft $(\mathrm{N})$ & Diff (\%) \\
\hline Paratill $^{\mathrm{TM}}$ & 3.0 & 18.9 & 17.9 & -5.3 & 34,130 & 33,589 & -1.6 \\
\hline Paratill $^{\mathrm{TM}}$ & 5.8 & 26.4 & 25.6 & -3.0 & 32,719 & 39,740 & +17.7 \\
\hline Paratill $^{\mathrm{TM}}$ & 8.3 & 38.8 & 40.2 & +3.6 & 43,633 & 48,540 & +10.1 \\
\hline KMC & 2.9 & 17.7 & 17.3 & -2.3 & 32,450 & 33,442 & +3.0 \\
\hline KMC & 5.6 & 29.3 & 28.9 & -1.4 & 40,581 & 39,171 & -3.6 \\
\hline KMC & 8.0 & 38.1 & 40.0 & +4.9 & 44,559 & 47,319 & +5.8 \\
\hline
\end{tabular}

FC: fuel consumption; Est: Estimated; Diff: percent difference.

a Fuel consumption values calculated using Eq. (2) (Raper et al., 2005).

normal and fast speeds whereas slow speed generated significantly higher fuel costs. In a practical sense, the lowest operating fuel costs were found at the fast speed for the KMC and at the normal speed for the Paratill ${ }^{\mathrm{TM}}$. The speed difference to attain the minimum fuel cost could be contributed to shank design and soil interaction with the shanks. The minimum draft for the Paratill ${ }^{\mathrm{TM}}$ occurred at the normal speed generating a $0.2 \mathrm{~km} / \mathrm{h}$ difference between these implements at the normal speed (Table 2). Thereby, this lower draft and slight increase in speed generated the least operating fuel costs for the Paratill ${ }^{\mathrm{TM}}$ at the normal speed.

Table 4 presents the comparison between estimated and actual fuel consumption (FC) and draft. The differences in FC were small as indicated by the percent difference. The overall mean absolute percent difference between actual and estimated FC was 4.8\% which was considered small. While not presented, a strong linear relationship $\left(r^{2}=0.96 ; \quad\right.$ RMSE $\left.=1.9 \mathrm{~L} / \mathrm{h}\right)$ existed between the estimated and actual FC values with the largest deviation occurring at the higher FC values. These results confirmed the accuracy of Eq. (2) to compute FC for this John Deere 8300 tractor. For draft, the Paratill $^{\mathrm{TM}}$ generated the largest differences between actual and estimated draft load at the normal and fast speeds. The overall mean absolute percentage difference between actual and estimated draft was $8.2 \%$. Resulting draft differences were well within the $50 \%$ variability stated by ASABE standard D497.6 (ASABE Standards, 2009a) thereby suggesting that the current equation can be used for these subsoiling implements.

In summary, the KMC fast treatment produced the highest draft but the treatment plots for this implement had the lowest MC but high CI. This result indicated that soil properties may have impacted this treatment. However, soil properties for the other treatments were considered similar. Therefore, we felt that soil properties did not fully explain the reported performance results but rather the effect of speed treatments overrode the soil property effects on equipment performance. The fast speed showed considerably higher productivity rates for both implements as would be expected. However, fuel costs for operating these implements were different with the lowest costs occurring at the normal speed for the Paratill and the fast speed for the KMC. During testing with the fast speed, the tractor showed slight signs of overloading so it is recommended that tillage should be performed in the range of $5.8-8.3 \mathrm{~km} / \mathrm{h}$ since operating at the fast speed could increase yearly maintenance costs. However, the speed at which tillage is performed should be based on the tractor's capability and soil conditions during operation. A quick comparison indicated that ASABE Standard D497.6 was suitable for estimating draft for these subsoil tillage implements. Future research needs to be conducted to evaluate the below ground effectiveness of these implements to breakup soil compaction at these different operating ground speeds.

\section{Conclusions}

Results for this study indicated that ground speed (transmission gear selection) impacted tractor fuel usage and thereby costs along with productivity rate for two subsoil tillage implements. Operating at fast speeds increased draft, fuel consumption, axle torque, and power for both the Paratill ${ }^{\mathrm{TM}}$ and KMC implements. For the most part, horizontal draft load, required tractor power and tractor fuel consumption increased with ground speed for both implements. However, the lowest draft $(32,719 \mathrm{~N})$ for the Paratill occurred at the normal speed while minimum draft occurred at the slow speed for the KMC. Statistical differences in vertical forces existed between the implements with the KMC generating negative values (upward force) and the Paratill positive values. Thereby, the final tillage depth for the Paratill was $2.2-4.8 \mathrm{~cm}$ deeper over the KMC. Fuel consumption increased by $40 \%$ (slow vs. normal), $47 \%$ (normal vs. fast) and $105 \%$ (slow vs. fast) for the Paratill. The KMC produced a $66 \%$ increase (slow vs. normal) and a $30 \%$ increase (normal vs. fast) in fuel consumption. The productivity rates for both implements increased with speed with the high speed generating values of 4.55 and $4.35 \mathrm{ha} / \mathrm{h}$ for the Paratill and KMC, respectively. Of interest, the Paratill normal speed produced the lowest fuel cost ( $\$ 5.10 / \mathrm{ha}$ ) while the fast speed produced the lowest fuel costs for the KMC ( $\$ 5.35 / \mathrm{ha})$. Comparisons between estimated and measured horizontal draft (ASABE Standard D497.6, 2009a) and tractor fuel consumption (Raper et al., 2005) indicated good relationship for both implements used in this study. Percent difference between actual and estimated draft ranged from $-1.6 \%$ to $17.7 \%$ with only small differences computed for fuel consumption $(-5.3 \%$ to $4.9 \%)$. Therefore, equations for estimating draft of tillage implements within ASABE Standard D497.6 can be used for these type implements.

\section{Acknowledgements}

The authors would like to thank Tyrel Harbuck, Jerry Carrington and Eric Schwab who assisted with this research effort. A special thanks is extended to the reviewers who provided constructive feedback. We also appreciate the support provided by the USDAARS National Soil Dynamics Laboratory and the Alabama Agricultural Experiment Station. Partial funding for this project was provided through a special grant from CSREES-USDA entitled, "Precision Agriculture - Alabama" and the Alabama Wheat and Feed Grain Commodity group.

\section{References}

ASABE Standards, 2009a. D497.6: Agricultural Machinery Management Data ASABE, St. Joseph, MI.

ASABE Standards, 2009b. D496.3: Agricultural Machinery Management. ASABE, St Joseph, MI.

Baldwin, K.R., 2006. Conservation tillage on organic farms. Center for Environmental Farming Systems Organic Production series. North Carolina Cooperative Extension Paper No. AG-659W-02.

Bashford, L.L., Kocher, M.F., Tibbetts, T.S., 1999. Wide tires, narrow tires. SAE Trans. 108 (2), 72-78

Bigham Brothers, 2009. Bigham Brothers Inc. Lubbock, TX. Available at: www. bighambrothers.com. (accessed 20.05.09).

Box, J.E., Langdale, G.W., 1984. The effects of in-row subsoil tillage and soil water on corn yields in southeastern Coastal Plain of the United States. Soil Till. Res. 4(1), $67-78$. 
Busscher, W.J., Karlen, D.L., Sojka, R.E., Burnham, K.P., 1988. Soil and plant response to three subsoiling implements. Soil Sci. Soc. Am. J. 52 (3), 804-808.

Chancy, H.F., Kamprath, E.J., 1982. Effects of deep tillage on $\mathrm{N}$ response by corn on a sandy coastal plain soil. Agron. J. 74 (1982), 657-662.

Free, G.R., Lamb Jr., J., Carleton, E.A., 1947. Compactibilty of certain soils as related to organic matter and erosion. J. Am. Soc. Agron. 39 (1947), 1068-1076.

Grisso, R.D., Pitman, R.M., 2001. Gear up and throttle down - saving fuel. Virginia Cooperative Extension Paper No. 442-450.

Jenane, C., Bashford, L.L., Monroe, G., 1996. Reduction of fuel consumption through improved tractive performance. J. Agric. Eng. Res. 64 (2), 131-138.

Kamprath, E.J., Cassel, D.K., Gross, H.D., Dibb, D.W., 1979. Tillage effects on biomass production and moisture utilization by soybeans on coastal plain soils. Agron. J. 71 (1979), 1001-1005.

Howard, R.F., Singer, M.J., Frantz, G.A., 1981. Effects of soil properties, water content, and compactive effort on the compaction of selected California forest and range soils. Soil Sci. Soc. Am. J. 45 (2), 231-236.

Larson, W.E., Allmaras, R.R., 1971. Management factors and natural forces as related to compaction. In: Compaction of Agricultural Soils, ASAE, St. Joseph, MI, pp. 367-427.

Ohu, J.O., Ekwue, E.I., Folorunso, O.A., 1994. The effect of addition of organic matter on the compaction of a vertisol from Northern Nigeria. Soil Technol. 7 (2), 155-162.

Raper, R.L., 2005. Force requirements and soil disruption of straight and bentleg subsoilers for conservation tillage systems. Appl. Eng. Agric. 21 (5), 787-794.

Raper, R.L., Washington, B.H., Jarrell, J.D., 1999. Technical notes: a tractor-mounted multiple-probe soil cone penetrometer. Appl. Eng. Agric. 15 (4), 287-290.
Raper, R.L., Bergtold, J.S., 2007. In-row subosiling: a review and suggestions for reducing cost of this conservation tillage operation. Appl. Eng. Agric. 23 (4), $463-471$.

Raper, R.L., Schwab, E.B., Balkcom, K.S., Burmester, C.H., Reeves, D.W., 2005. Effect of annual, biennial, and triennial in-row subsoiling on soil compaction and cotton yield in Southeastern US silt loam soils. Appl. Eng. Agric. 21 (3), 337-343.

Reeves, D.W., Touchton, J.T., 1986. Subsoiling for nitrogen applications to corn grown in a conservation tillage system. Agron. J. 78 (5), 921-926.

Schrock, M.D., Hatteson, D.K., Thompson, J.G., 1982. A gear selection aid for agricultural tractors. ASAE Paper No. 825515. ASAE, St. Joseph, MI.

Sene, M., Vepraskas, M.J., Naderman, G.C., Denton, H.P., 1985. Relationships of soil texture and structure to corn yield response to subsoiling. Soil Sci. Soc. Am. J. 49 (2), 422-427.

Sumner, C., 2007. Kelley Manufacturing Co. (KMC). Personal communication. April 25, 2007.

Turner, R.J., 1993. A simple system for determining tractive performance in the field. ASAE International Winter Meeting, Chicago, Illinois. ASAE Paper No. 931574. ASAE, St. Joseph, MI.

Wagger, M.G., Vepraskas, M.J., Denton, H.P., 1992. Corn grain yield and nitrogen utilization in relation to subsoiling and nitrogen rate on Paleudults. Agron. J. 84 (5), 888-892.

Zoz, F.M., Grisso, R.D., 2003. Traction and tractor performance. ASAE Distinguished Lecture Series, Tractor Design No. 27. ASAE Publication Number 913 C0403. ASAE, St. Joseph, MI 